\title{
Review of Peter Dietsch's Catching capital: the ethics of tax competition. New York: Oxford University Press, 2015, 280 pp.
}

\author{
GILLIAN BROCK \\ University of Auckland
}

This excellent book explores normative issues related to tax competition among states and proposes solutions to core problems identified. The two main questions which the book tackles are: What, if anything, is wrong with tax competition? And, if there is something ethically problematic, what should be done? Dietsch argues that "tax evasion and the shifting of profits to low-tax jurisdictions represent egregious forms of free-riding on the part of capital owners and one of the most blatant injustices of modern economic societies. We need to get a grip on them" (p. 223). As far as I am aware, this is the only book-length normative assessment of tax competition available and, as such, it makes a highly original contribution to important literatures. This work, principally in economic philosophy, blends issues and insights from at least four different disciplines, namely political philosophy, economics, political sciences, and international tax law. It is accessibly written and aims to reach a broad audience including philosophers, economists, political scientists, law theorists, along with policymakers and members of international organizations. It is centrally focused on the normative underpinnings of how the international tax regime should be organized. But it also offers concrete proposals about how to create institutions and policies that would best match the theoretical analysis and bring its core normative insights into being.

Dietsch argues that enormous private wealth is hidden in tax havens and restoring fiscal control to states will require more effectively catching this capital, so that those who have a right to tax capital are able to do this effectively. We have to reform the international fiscal policy regimes so that effective taxation is possible. These goals require answering a number of core questions.

If some coordination in tax policy is required to respond to tax competition, what will be the implications for states' fiscal sovereignty? Can one regulate tax competition without calling for an 
outright harmonization of tax rates? If so, how should we strike a balance between the fiscal autonomy of one particular state and the externalities this autonomy creates for other states? And supposing that reforming the system through multilateral regulation of tax competition is not politically feasible, are there compensatory duties that the winners of tax competition owe the losers? Last but not least, could it be that regulating tax competition will be economically inefficient (p. 7)?

So, to begin the sketch of his answers to some of these questions, what kinds of tax competition are worrisome? Dietsch identifies three kinds. First, states compete for foreign direct investment which involves relocation of real economic activity. Second, there is competition for portfolio capital. "Individuals shift some of their wealth in the form of cash deposits, equity, and security holdings offshore-which in fact means nothing other than 'abroad' in the financial world-in order to avoid paying capital gains tax" (p. 3). Approximately 10\% of European wealth is held offshore, while the figure for Latin America is $50 \%$, and the Middle East, $70 \%$ (p. 3). Third, states also compete for paper profits of multinational enterprises (MNEs). Using a staggering array of methods (such as manipulative transfer pricing schemes), MNEs shift profits from high to low tax rate jurisdictions. As one example, in 2009 Google Inc. was able to shift profits through Ireland, the Netherlands and Bermuda to cut its taxes dramatically to around $2.4 \%$, far below the US corporate tax rate of 35\%. So successful are these methods that 39\% of Fortune 500 companies that were profitable for each year between 2008 and 2013 paid zero (or less) tax in one or more of those 5 years. Indeed, such practices have become an essential part of being competitive.

It is important to note that in the wake of all this tax competition and especially abusive offshoring practices, the tax burden has shifted with regressive effects to more immobile factors such as consumption and labour.

Part I investigates the nature of the wrongs associated with tax competition and explores solutions to remedy the wrongs identified. States enjoying fiscal autonomy is a central aspect of Dietsch's just worldview. Tax competition can undermine that autonomy. Fiscal selfdetermination involves two basic choices. One concerns the size of the public budget and the second concerns the level of redistribution (p. 35).

Suppose the citizens of Sweden prefer larger public budgets and levels of redistribution to the citizens of the United Kingdom, and taxes highincome earners and corporations in Sweden at higher rates than those in 
the UK to achieve these goals. Those in Sweden will therefore have some incentive to shift capital and income to the United Kingdom. If one aims to protect fiscal autonomy, this is an inevitable feature of fiscal interdependence. He thinks that, prima facie, shifts from Sweden to the United Kingdom in this scenario are probably "benign from a normative viewpoint" (p. 78). He believes "there will be some shifts in tax base between countries in response to differential tax rates that should count as unproblematic. The basic challenge of this book is to identify where the boundaries of the fiscal autonomy prerogative should lie, and what institutions might serve to protect them" (p. 79, emphasis in original). If capital flows away from Sweden in response to the lower tax rates resulting from English democratic choices, other countries cannot object. However, if states lower tax rates "on strategic grounds to lure foreign capital, then other countries will have a legitimate complaint if they can show that the policy has a negative impact on their aggregate fiscal selfdetermination" (p. 183).

We should design principles to regulate fair tax competition. Two are offered: the membership principle and the fiscal policy constraint. The membership principle is reasonably easy to understand: persons (both natural and legal) should pay tax in the state where they are a member. The fiscal policy constraint is much more complex (and also more difficult to appreciate how it would unproblematically do real work in practice). According to this constraint, "any fiscal policy of a state is unjust and should be prohibited if it is both strategically motivated and has a negative impact on the aggregate fiscal self-determination of other states" (p. 80, emphasis in original).

Dietsch also explores the institutional structure that is required to implement these principles effectively. He proposes the establishment of an International Tax Organisation (ITO) in which the rules are designed and negotiated in line with the membership principle and the fiscal policy constraint. All states would be members and adequately represented in the decision-making process. Practices such as bank secrecy and refusals to exchange information would be prohibited. Several intermediate steps would be needed to achieve these goals such as stronger deterrents for tax fraud including criminal prosecutions.

He proposes a number of important policies that I cannot hope to do justice to here given space constraints. Importantly, one of the policies he offers is a version of unitary tax with formulary apportionment. On this proposal, one first calculates the worldwide profits of MNEs and then 
apportions "each country's right to tax a part of these profits through a previously agreed formula" (p. 76). While some of these proposals look exclusively at sales as the relevant variable in the apportionment formula, the proposal he endorses is a lot more nuanced and combines a host of factors. Dietsch also usefully compares his own solution with those policy initiatives aimed at addressing tax evasion and avoidance recently offered by the OECD and European Union, so we can appreciate some of the considerable advantages his proposal has.

Part II addresses challenges for his account, such as the objection that any form of tax cooperation (including his own) will be inefficient. Another important objection is that tax cooperation infringes sovereignty inappropriately. He also argues that under the system of tax competition as it operates today, the winners of our current tax competition regime have moral obligations to compensate the losers. Dietsch carefully considers matters of transitional justice involving compensatory duties. Those states that experience net gains from tax competition incur duties to compensate the net losers.

For the objections Dietsch does consider, he does an excellent job disarming their force. My concern is that he leaves unaddressed several other challenges that are potentially quite serious, and which threaten some of the core goals of his ambitious programme of research. This is not a complaint about what he chooses to do in Catching capital. One can, after all, only do so much in the scope of one book. Rather, the challenges I present are invitations for him to develop his account by tackling what I see as some of the more difficult issues his position faces.

One of Diestch's important aims in the book

[...] is to promote reforms that would bring all stakeholders of capitalism back under the control of democratic decision making. A renewed and sustainable social contract will only be possible if the bargaining positions of labour and capital at the negotiating table become once again symmetrical (p. 21).

He aims to offer a vision according to which this much-needed symmetry is possible. I am much less optimistic about how this goal will be achieved through the mechanisms offered. In fact, I do not believe this symmetry will be meaningfully achieved by the measures proposed. Indeed, if promoting a more even relationship between labour and capital is one of the core goals, (1) the proposed reforms need to go much further, (2) the expressed primary goal of "fiscal self-determination" is somewhat 
in tension with achieving a more favourable bargaining position between labour and capital, and (3) he needs to give other goods that tax competition undermines more weight than he has so far.

In order to explain these points we might start by asking: What goods are threatened by tax competition? Two core goods are identified as being endangered. The first and by far the most important for Dietsch is that tax competition undermines the fiscal self-determination of states. The second is that tax competition also widens inequality in two ways, by increasing income gaps between rich and poor countries and by widening gaps between capital owners and others. I believe that if Dietsch takes the first goal of fiscal self-determination seriously he should be more concerned to prioritize the second goal by aiming to reduce inequality. Fiscal self-determination is something of a myth even in some of the most robust democracies currently in existence. To give one example of this, consider the ways in which election funding practices give rise to a system in which corporations and wealthy individuals get privileged access to regulators and legislators, and are frequently able to influence policy that bends in the direction of promoting their interests. In contrast to the rather idealized version of citizens determining fiscal policy through their own choices, primarily through the mechanisms of elections, it can be rather dangerous to assume that fiscal policies are truly a reflection of the will of the people, even in democracies regarded as well-functioning. This is especially the case where there is already wide inequality within a state.

In contemporary democracies the legislature is, to varying degrees, captured by corporations that have powerful resources to invest in ensuring that it is so captured (Brock 2014b). This is exacerbated by the revolving door (in which employment in the private sector follows periods of government service), and the reverse revolving door, which involves moves from the private sector to government. Laws are written by those who heavily favour the interests of corporations that have much invested in making sure both the size of the public budget is small and levels of redistribution are kept at minimal levels. Corporations also have a strong general interest in light regulatory regimes and it is far from clear that any current governments would have any genuine interest in establishing an ITO, which is a key component to Dietsch's overall solution. In practice, fiscal "self-determination" tends to mean that those who are in power can and do use that power to write rules (regulations, legislation, and policy) that can widen inequality, further entrench an unjust status quo, and 
promote the interests of capital over labour (Brock 2014a). Under the guise of fiscal self-determination, the status quo tends to prevail and that is to maintain a structure that strongly promotes the interests of capital over labour. So the twin goods that lie at the heart of the analysis of why tax competition is thought to be unethical are actually in some tension. A better way to really assure genuine fiscal self-determination might be to prioritise the second set of concerns about stemming inequality rather than privileging fiscal self-determination.

So, the idea that government policy reliably tracks citizens' preferences and that citizens choose at the ballot box both the size of the public budget and the level of redistribution, while noble, is undermined so badly in practice, one wonders what use can be made of these ideas as sufficiently indicative of the will of the people that needs respecting. This rather makes a mockery of putting so much weight on democratically revealed fiscal preferences since, for the most part, these are not relevant in the writing of fiscal law in most so-called democracies.

Presumably, Dietsch is aware of these kinds of issues, noting democracy's flaws on occasion (e.g., p. 182). Also, all too briefly towards the very end of the book, he notes "the elephant in the room," which he identifies as corporate lobbies (pp. 214-216). He thinks that there is good potential for workers and consumers to form important coalitions to advance the regulation of tax competition agenda. These two groups in particular have, after all, been net losers from tax competition and have had their tax burdens increased, as payroll and consumption taxes have increased significantly. But there is more than one elephant in the room here. Arrangements for funding of elections, significant worries about regulatory capture, the revolving door between government and the private sector, widening inequality, inter alia, mean that there is only so much a coalition between consumers and workers can really achieve, given the extraordinary asymmetry in power enjoyed by the global advantaged. I think this cluster of concerns deserves more than a twopage concession towards the very end of the book. What mechanisms can be introduced to combat these worries? I hope Dietsch will develop his views to address such issues.

The second set of problems I raise here concerns the compensatory duties identified. As mentioned, Dietsch offers a state-centric account of compensation. Individual states that benefit from tax competition owe compensation to those states that are net losers: "the net winners of tax competition-that is, those states that, on balance, experience capital 
inflows-incur a duty to compensate the net losers" (p. 191). Against feasibility concerns, Dietsch argues that making the case for these compensatory duties is not "actually to see them paid" (p. 192). Rather, these arguments strengthen the hand of those who have fared poorly under tax competition and helps improve the prospects for wider institutional reforms. Invoking Pablo Gilabert's notion of dynamic duties he says that even if "a feasibility constraint prevents us from discharging duty $\mathrm{X}$ at time $\mathrm{t}_{1}$, we may still have a duty $\mathrm{Y}$ to do something that will increase our likelihood of being able to discharge duty $\mathrm{X}$ at time $\mathrm{t}_{2}$ " ( $\mathrm{p}$. 193). He argues that making the case for compensatory duties is of this kind and should help to have a "positive influence on the trajectory of events" (p. 193).

While I think invoking Gilabert's account is useful, I think the statecentric model for compensation might well blind us to some core relevant issues. There are so many individual variations in who exactly benefited from the unjust system. Surely, we might argue, that those who contributed to the design of the unjust system, who benefited greatly from it and have great capacity to fix it might be more responsible for compensation than those who did not? Or, even if we bracket the causal or contributory component, those who benefited greatly and have great capacity to fix it should do more than those not similarly situated. So, who should compensate, is a question that remains unconsidered. I think a more fine-grained analysis is required and that simply considering the matter from the perspective of states is too crude. To give a concrete case of why this question is relevant, consider the case of tax professionals.

Tax professionals, including and especially large multinationals firms of accountants, financial advisors, lawyers, and bankers, have not only designed the architecture that facilitates wide-scale abusive tax schemes necessary for destructive forms of tax competition to flourish, but have also been instrumental in implementing these schemes (Brock and Russell 2015). They have also personally and professionally benefited extensively from these arrangements and have significant capacity to remedy the injustices identified. Why should this group of tax professionals not be called upon to make a huge contribution to any compensation that is owed? And what about the high net worth individuals and multinational corporations that again have been such large beneficiaries, have fuelled the demand for such services, and have enormous capacity to compensate? Similarly, what about all those banks that facilitated abusive 
tax practices, specifically targeting high net worth individuals and promoting their services to them?

The state-level analysis also spreads the compensatory load to many within a state, including the worst off and least responsible for the deprivation caused by tax competition. Why think they should carry some part of the burden of such compensation given the much more obvious involvement of tax professionals and their clients? Finally, an important objection to this country-by-country analysis is that some of the worst offenders might be able to fudge their real residency quite easily so that they are not counted anywhere in the calculation of who owes what to whom.

Note that the whole argument for compensation is one essentially based on requirements of justice. Justice considerations might also suggest that the ITO should be more involved in tax policy and should have broader powers to remedy other defects. So, since inequality undermines fiscal self-determination, perhaps the ITO should set minimum tax rates, requirements on the size of the public budget, or levels of redistribution, to address inequality. Furthermore, the ITO would have a mandate to make such recommendations on the grounds that this undermines fiscal self-determination. Once established, the ITO might also drift into proposing other robust taxation policies, including the implementation of international tax and transfer schemes, specifically as a way to restore fiscal self-determination or correct for externalities related to current practices that undermine fiscal self-determination (Brock 2008, 2009). It is not clear how Dietsch would be able to allay the fears of those who have such concerns, since these policies would be most consistent with promoting the goods he articulates as valuable.

Overall, this is an exceptional book that is well worth reading. I hope Dietsch will develop his research to take account of these concerns.

\section{REFERENCES}

Brock, Gillian. 2008. Taxation and global justice: closing the gap between theory and practice. Journal of Social Philosophy, 39 (2): 161-184.

Brock, Gillian. 2009. Global justice: a cosmopolitan account. Oxford: Oxford University Press.

Brock, Gillian. 2014a. Global poverty, decent work, and remedial responsibilities: what the developed world owes to the developing world and why. In Poverty coercion, and human rights, ed. Diana Tietjens Meyers. Oxford: Oxford University Press, 119-145. Brock, Gillian. 2014b. Institutional integrity, corruption, and taxation. Edmond J. Safra Research Lab Working Papers, No. 39, March 13. http://ssrn.com/abstract=2408183. 
Brock, Gillian and Hamish Russell. 2015. Abusive tax avoidance and institutional corruption: the responsibilities of tax professionals. Edmond J. Safra Research Lab Working Papers, No. 56, February 17. http://ssrn.com/abstract=2566281.

Gillian Brock is professor of philosophy at the University of Auckland in New Zealand. Her recent books, largely in the area of global justice, include Debating brain drain (Oxford University Press, 2015, with Michael Blake) and Global justice: a cosmopolitan account (Oxford University Press, 2009). She also has many interdisciplinary interests some of which lie at the intersection of philosophy and public policy. For instance, during her recent fellowship at the Safra Center for Ethics at Harvard University she has been working on institutional corruption.

Contact e-mail: <g.brock@auckland.ac.nz>

Website: <http://www.arts.auckland.ac.nz/people/gbro064> 